This item was submitted to Loughborough's Research Repository by the author.

Items in Figshare are protected by copyright, with all rights reserved, unless otherwise indicated.

\title{
Ford, book history, and the canon
}

PLEASE CITE THE PUBLISHED VERSION

https://www.routledge.com/The-Routledge-Research-Companion-to-Ford-Madox-Ford/Haslam-ColombinoOMalley/p/book/9781472427380

\section{PUBLISHER}

(c) Routledge

\section{VERSION}

AM (Accepted Manuscript)

\section{PUBLISHER STATEMENT}

This is an Accepted Manuscript of a book chapter published by Routledge in The Routledge Research Companion to Ford Madox Ford on 3 December 2018, available online: http://www.routledge.com/9781472427380.

\section{LICENCE}

CC BY-NC-ND 4.0

\section{REPOSITORY RECORD}

Jaillant, Lise. 2018. "Ford, Book History, and the Canon”. Loughborough University. https://hdl.handle.net/2134/21945. 


\section{Lise Jaillant}

\section{Ford Madox Ford, Book History and the Literary Canon ${ }^{1}$}

Surprisingly, very few book historians have paid attention to Ford Madox Ford. ${ }^{2}$ Yet, his career was varied and touched on many aspects of Robert Darnton's communications circuit, which analyses the way books come into being and spread through society. The circuit runs from the author to the publisher, the printer, the bookseller and the reader. When Darnton proposed his influential model in 1982, his objective was to help book historians have a broad overview of their field instead of losing themselves in an 'interdisciplinary run riot' (67). Scholars cannot do everything, and some of them choose to specialize in the history of authorship, printing, publishing or reading. But for Darnton, it was important to keep in mind that these activities were part of a whole circuit. Ford is a good example of a literary man who was not 'just' an author. He also shaped literary production as the editor of the English Review and the transatlantic review. Throughout his long career, he was a tastemaker who helped younger writers get published and noticed. He worked with prominent literary agents (including James B. Pinker and William Bradley) and negotiated himself with numerous publishers on both sides of the Atlantic. He targeted various audiences by writing in several genres, from children's fairy tales to historical sagas, from war novels to fictional autobiographies, from critical monographs to travel reminiscences. Ford was of course a reader himself, and wrote influential accounts of Joseph Conrad's and Henry James's work.

Since the 1990s, scholarly interest in Ford has come mainly from modernist studies, and has reflected the priorities of this field. As Rebecca Walkowitz and Douglas Mao famously put it, New Modernist Studies is characterized by temporal, spatial and vertical expansion (with a reconfiguration of the boundaries between 'high' and 'low' cultural forms). Ford fits particularly well in this context. He was heavily influenced by nineteenth-century artistic movements (including Pre-Raphaelitism). His "literary career began a decade before Edward VII acceded to the throne in 
1901," writes Max Saunders in his introduction to the 'Edwardian Ford,' the 2013 issue of the International Ford Madox Ford Studies series (13). Moreover, Ford lived and published texts in Europe and the United States. And he actively engaged with popular culture, while defending 'highbrow' texts such as James Joyce's Finnegans Wake and Gertrude Stein's The Making of Americans (both serialized in his transatlantic review). With the rise of interest in modernist little magazines, Ford's editorial activities have also been scrutinized. Indeed, the sub-field of 'modernist print culture' has become prominent and transformative, as Ann Ardis notes in a recent review essay. She gives the example of the publication of Peter Brooker and Andrew Thacker's threevolume Oxford Critical and Cultural History of Modernist Magazines (which includes a chapter on Ford and the English Review):

The gravitas of a multivolume series with a premier university press and the hugely ambitious scale of this collaborative research enterprise exemplify the maturity as well as the long-term impact of research on modernism, modern media technologies, book history, and periodical studies. (2015: 814)

Although their subject matter sometimes overlaps, the theoretical framework and methodology of modernist scholars can be different from that of book historians. For example, in The Public Face of Modernism: Little Magazines, Audiences, and Reception, Mark Morrisson takes the English Review as an example of Ford's ambition to 'engage the public sphere' and 'create a discursive space for disinterested critical deliberation as grounded in Enlightenment thinking' (2001: 17, 18). Jürgen Habermas's concept of the public sphere is also central to Patrick Collier's forthcoming monograph Modern Print Artifacts (which discusses Ford's poems published by Harold Monro's Poetry Bookshop). Book historians are much more suspicious of broad theoretical claims, and if they refer to the work of Habermas, Benedict Anderson, or Pierre Bourdieu, they will also engage with the minutiae of archival work and bibliographical research. Both Morrisson and Collier used archives, and their research is of interest to book historians - so putting limits on what is and is not 
book history is difficult. But as Leslie Howsam bluntly puts it, 'most of us know it when we see it, and can identify that brand of scholarship which claims to be book-historical but is really just playing around with the fashionable terminology of 'print culture' or 'print capitalism' or whatever, without grappling with the archival and bibliographic realities. ${ }^{3}$

So what can book history do to enrich our understanding of Ford Madox Ford? There are many ways to answer this question. In Reading and the First World War, edited by Shafquat Towheed and Edmund King, Max Saunders examines Ford's reading habits, and the representation of reading in his work, particularly in Parade's End (2015: 63). The history of reading can also draw parallels between 'elite' readers and common readers. This approach is of particular interest for a writer like Ford, who was eager to correspond with ordinary readers and mentor younger people. Publishing history is also a productive way of approaching Ford. In particular, his relationship with commercial publishers has seldom been examined. ${ }^{4}$ This is a general characteristic of modernist studies, which tends to privilege small-scale 'institutions of modernism' (little magazines and small presses). In the case of Ford studies, the focus has mostly been on magazines that Ford edited for less than three years of his life (1908-1910 for the English Review; 1924 for the transatlantic review). During the course of his life, he published seventy-eight books - the first one in 1891 with T. Fisher Unwin and the last in 1938 with the Dial Press (Ludwig 1965: vii). This forty-seven-year-long experience of working with book publishers has so far attracted little attention. To paraphrase John Sutherland (1988), I would say that publishing history is a hole at the center of Ford studies. Fortunately, a few recent articles have started addressing this gap: Sara Haslam has questioned 'how the Edwardian world of publishing affected Ford together with and as opposed to his contemporaries - including Conrad' (2013: 35), and Carey Snyder (2012) has looked at the publication of Ford's When the Wicked Man, a novel that takes the New York publishing business as its subject matter.

Drawing on this emerging scholarship, my chapter explores Ford's position in the literary canon, in relation to publishing history. Ford's constant change of publishers, his inability to have a 
collected edition of his work published during his lifetime, and his exclusion from prominent series of classics had a significant impact on his canonicity. ${ }^{5}$ Writing about Virginia Woolf's Uniform Edition published by the Hogarth Press from 1929, J.H. Willis argues that 'to put a living novelist's works into a standard edition is to make a claim for the permanence and importance of the writer's work, to establish a canon, to suggest the classic' (1992: 156). Woolf was not the only modernist writer to be marketed as 'classic' while she was still alive. As early as 1926, James Joyce's Dubliners was included in uniform series of reprints (the Travellers' Library in the UK and the Modern Library in the US). By the late 1920s and early 1930s, younger writers that Ford had helped at the beginning of their careers (D.H. Lawrence, Wyndham Lewis, Ernest Hemingway) also appeared in well-known series of classics. Ford's marginalization in this publishing context meant that it was difficult for instructors to teach his work, and partly explains his delayed entry into the literary canon.

\section{Ford, Publishers and the Literary Canon}

Nobody doubts that Ford is now a canonical writer, read within and outside the education system. Academic publishers have issued books and critical editions to help students new to his work. ${ }^{6}$ The TV adaptation of Parade's End, premiered on BBC Two in August 2012, featured wellknown actors (including Benedict Cumberbatch) and was accompanied by the publication of a tie-in edition. The BBC list of 'the 100 Greatest British Novels,' released in December 2015, includes The Good Soldier and Parade's End (Ciabattari). This recognition has come late, with a first wave of scholarship in the 1960s (with the work of David Harvey and Richard Ludwig for example). When explaining Ford's fluctuating reputation, scholars have focused on two main reasons. First, Ford was a difficult man, who had many powerful enemies eager to downplay his literary talent. As Saunders put it in his 1996 biography, 'it is only now, half-a-century after his death, when most of the personal animosities have burned themselves out, that it becomes possible to gauge and judge' (I: vi). The second reason is the unequal quality of Ford's work. 'He is only occasionally great,' 
Saunders writes, thus echoing Mizener's earlier statement ('the very quantity of Ford's work has tended to obscure the best of it' [1971: xxiii]). Ford's large and uneven production was undoubtedly a major obstacle to his entry into the literary canon at the time when New Critics privileged close attention to the literary text.

But there is yet another reason, which has not been sufficiently explored: Ford's constant change of publishers made it difficult to market him as a 'classic' by issuing a collected edition or including his work in a series of classics. By the end of Ford's career, his texts were scattered across more than twenty British publishing houses - from small presses (the Poetry Bookshop) to mid-size literary publishers (Duckworth, John Lane, Chatto \& Windus, Martin Secker, Victor Gollancz) to large 'enterprising' companies (Hodder \& Stoughton). In addition, Ford also had several American publishers, including J. B. Lippincott, William Edwin Rudge and Horace Liveright. Only three of Ford's UK publishers issued more than three of his books: Duckworth, Alston Rivers and John Lane. None of them made a lot of money with Ford's books. He was particularly disappointed by Duckworth's sales of the Tietjens tetralogy, telling Percival Hinton that whereas 'in the United States 50,000 people had bought Last Post within a fortnight of its appearance,' 'just under 1,000 people had bought the English edition of No More Parades and just over 1,000 A Man Could Stand Up., ${ }^{7}$

Ford's disappointment with his low sales partly explains his frequent quarrels with publishers and his inability to build long-term relationships with them. This aspect of Ford's life is well known, because of his extant correspondence with members of the book trade. As Saunders rightly points out, 'publishers and agents keep better records than many friends and lovers' and 'Ford's querulous, dismayed letters, in which he emphasized the role of important-but-neglected writer, tended distortingly to dominate Mizener's biography' (1996 I: 12). These letters are often taken as examples of Ford's antagonism towards commerce. According to Mizener, 'all his life Ford, like his grandfather Brown, contributed to his own lack of success by assuming that it was not only possible for him to dictate to editors and publishers but necessary to his dignity as a gentleman 
and author that he do so' $(1971: 7){ }^{8}$

It is certainly true that Ford presented himself as an artist radically different from (and superior to) the world of trade. In July 1929, for example, he wrote to the New York literary agent Bernice Baumgarten to complain after Viking Press rejected his novel When the Wicked Man:

I was trying in the book a technical experiment which seems to me to have been successful and you are, I suppose, aware that I have been a good deal praised for the technique of my fiction and that I have had a good deal of influence on the technique of the more modern novelists of today. It seems therefore more likely that I am right in the matter than a group of tradesmen who have no literary experience, whatever their skill or want of skill in marketing the literary products of others. ${ }^{9}$

Here, Ford opposed innovation to feebleness, the solitary artist to the 'group of tradesmen.' This discourse fits well with the traditional image of the modernist artist hostile to a debased commercial culture. But it also hides an important aspect of Ford's career - his ability to survive (and even thrive) in a highly-competitive literary marketplace by constantly exploring new opportunities on both sides of the Atlantic. For all his proclaimed disdain for publishers, Ford knew he needed them to achieve long-term recognition and status as a 'classic' writer.

\section{Lobbying Publishers for a Collected Edition}

The scholarly focus on Ford's editorship of little magazines has led to a rather distorted view of his business aptitudes. Looking at the commercial failure of the English Review, Mark Morrisson argues that Ford 'was notoriously inept at handling advertising and business affairs' (2001: 32). In her study of the finances of the same review, Nora Tomlinson notes that Ford was 'hopeless with money' (2010: 150). Haslam echoes this consensus, writing that 'his business head was such that he often deduced an inverse relationship between financial and literary success.' And she adds: 'Ford also both needed, and enjoyed having, money - if only to give away or to spend on 
another hugely valuable literary venture with a terrible business model' (2013: 42). But Ford's career should not be limited to his disastrous management of the English Review and the transatlantic review. If we move away from these little magazines, a more nuanced view of his business skills emerges. As Joseph Wiesenfarth points out, James Joyce was eager to ask Ford for advice when dealing with publishers (1991: 106). After Jonathan Cape bought the Egoist Press from Harriet Shaw Weaver, Joyce wrote to Ford to tell him about his royalty rate $(15 \%$, whereas 'The Egoist Press paid me 25\% and Shakespeare and Company $66 \%$ of net profit'). 'May I trouble you to let me know what you think of it,' wrote Joyce (Letters 3:93). In 1925, when Samuel Roth started to pirate Finnegans Wake in his review, Joyce told Weaver that 'nobody here, not even Mr Ford, can solve the problem of Two Worlds' (Letters 3:131). By that time, Joyce had more than two decades of experience dealing with publishers. The fact that he valued Ford's advice shows that the author of The Good Soldier was far from useless with business affairs.

In particular, Ford perfectly understood that to become a classic writer, he had to be marketed as such - hence his life-long ambition to have his work published in a collected edition. In 1915, the publisher Martin Secker had issued a Uniform Edition of Henry James's work, which included thirteen volumes by 1918 . That year, Ford wrote to Secker:

Do you think you would care to try a collected edition of my novels? It wd. suit me quite well if you began with a cheap edition of 'The Good Soldier,' 'Ladies Whose Bright Eyes,' 'Mr. Apollo,' and 'The Fifth Queen' - to see how they would go \&, if they proved successful enough to make it worth while, to go on with the others.

Ford added that he was not looking for 'large advances,' he just wanted to 'get [his] books under one roof. ${ }^{, 10}$ Four year earlier, he had told his agent James Pinker that he wanted 'stability': 'I can't think it to be either good or gracious to go jumping about from publisher to publisher as I have done in the past. ${ }^{, 11}$

Finding a long-term publisher and getting a collected edition were two sides of the same 
coin. Lacking the former made it difficult for Ford to obtain the latter - in contrast to other modernist writers with more stable relationships with publishers. When the Hogarth Press decided to issue a uniform edition of Virginia Woolf's work, Leonard Woolf wrote to only one firm (Duckworth) to obtain the right to reprint The Voyage Out and Night and Day. ${ }^{12}$ It took a month to settle the matter with Duckworth, and since the Hogarth Press had the rights for all the other titles, the Uniform Edition was published later in 1929. For Secker to publish the edition that Ford suggested, he would have had to negotiate with four different firms: Alston Rivers (the publisher of The Fifth Queen in 1906), Methuen (Mr. Apollo, 1908), Constable (Ladies Whose Bright Eyes, 1911) and John Lane (The Good Soldier, 1915). Unsurprisingly, Secker spared himself the trouble and expenses of buying rights from four competitors.

Ford then approached John Lane, who had already published several of his books (starting with The Simple Life Limited in 1911). In July 1920, Ford wrote to Pinker: 'I think the psychological moment is approaching when you might suggest to Lane that he produce the contract for my Collected Edition. ${ }^{13}$ Ford explained that he had made this suggestion during the war, shortly after the publication of The Good Soldier, and Lane had agreed. But once again, nothing came out of this proposal.

Having failed to interest a British publisher in his project, Ford turned towards the United States. ${ }^{14}$ In 1921, he wrote to H. S. Latham of Macmillan: 'I want to get into relations with a publisher with whom I could reasonably hope to remain for the rest of my life.' And he went on to explain that several of his books were out of print. 'This is naturally very disadvantageous to a writer like myself who have (sic) always written with a view to a steady and continuing, rather than an immediate and sensational, sale. ${ }^{15}$ Ford was undoubtedly aware of Macmillan's reputation as a 'list publisher' that relied heavily on its backlist (Feltes 1993: 28-29). For once, Ford seemed to have found the perfect publisher - but his literary agent died in the midst of the transaction, and he had to find an alternative. In 1922, he wrote to Edgar Jepson:

My quite firm resolution is to have nothing to do with any publisher who will not take up my 
work for good. America seems ready to provide that [...] Obviously, one does not stick to one's even firmest resolutions and if any English publisher approached me on bended knee and asked for the privilege of publishing the novel which I have in my drawer beneath this machine, and offered a large lump sum down for that privilege I should probably succumb to the temptation. But I see little likelihood of that occurrence. You see, I have written four or three - I am not sure which - books that ought to be 'classics' and from which I ought to draw a comfortable if small provision for my approaching old age. They are all out of print and unlikely to be re-published. ${ }^{16}$

Here, Ford explicitly linked his project to find a stable publisher and his ambition to have his books marketed as 'classics.' He showed remarkable entrepreneurship, crossing the Atlantic in the hope of finding new opportunities. The American book trade offered him increased sales (in 1927, the Literary Guild sold around 30,000 to 40,000 copies of his novel The Last Post [Saunders 1996 II: 326]). He also met American writers who would later help maintain his posthumous legacy: Glenway Wescott, William Carlos Williams, Katherine Anne Porter, Allen Tate, Caroline Gordon, and Edward Dahlberg. ${ }^{17}$ But he never managed to convince an American publisher to issue a collected edition of his work.

So what happened? Why did no one want to publish the collected edition of a well-known writer with respectable sales? Ford had approached the firm of Albert and Charles Boni, suggesting they issue his work 'in a uniform edition which would, he hoped, form the basis of a collected edition' (Mizener 1971: 353). The Boni brothers were initially interested. But in November 1928, Ford wrote to George Oppenheimer of the Viking Press to tell him that he had broken off his agreement with the Bonis - meaning that the project of collected edition would not go ahead. Ford then tried to convince Viking to take on all his work, telling Oppenheimer: 'I suppose you know that it is quite in $m y$ mind to give you all my books for good, for I hate changing publishers; and indeed nothing is more unprofitable. ${ }^{18}$ But Viking never published the edition that Ford coveted, 
nor did other publishers. In late 1933, Lippincott informed Ford that it would cost $\$ 5,000$ (the equivalent of around $\$ 90,000$ in 2015) to buy the plates and stocks of his books from all the publishing houses he had worked with. ${ }^{19}$ Once again, Ford suffered from his inability to build stable relationships with publishers.

Ford's When the Wicked Man exemplifies his growing frustration with the New York publishing industry. ${ }^{20}$ The novel centers on the Englishman Joseph Notterdam 'as the apparent defender of the once-genteel values of publishing and his partner William Kratch as the proponent of, at once, the apparently antithetical categories of modern literature and commodity-style marketing' (Snyder 2012: 140). Kratch seems to be modeled on Horace Liveright, who published all kinds of books - from T.S. Eliot's The Waste Land to Anita Loos's Gentlemen Prefer Blondes. When the Wicked Man appeared in 1931 under Liveright's imprint, before its release in Britain one year later. The publisher Jonathan Cape did not make a lot of money with the book: out of a printing of around 3,000, only 1,396 copies were sold (Harvey 1962: 77). The novel was probably a commercial failure in the United States as well, as no cheap edition ever appeared. Ford's work lacked market appeal, but his name was well known on both sides of the Atlantic. When the Wicked Man was reviewed in high-profile newspapers and magazines in the United States (New York Times, Chicago Daily Tribune) and in Britain (Manchester Guardian, Times Literary Supplement, Sunday Times, Saturday Review, Listener, Bookman, Spectator). Reviewing the book for the Observer, the writer and journalist Gerald Gould expressed a mix of admiration and puzzlement: 'Why is it that this man of indisputable genius, of extraordinary range of acquaintanceship with life and letters, should so frequently leave one feeling embarrassed and bewildered instead of satisfied?' And he added:

Well, it is no use pleading with Mr Ford. He is a man of genius and will please himself. $\mathrm{He}$ has no living superior in the task of painting the muddles, the disorders, the disappointments, the maddening irrationalities of life; and out of this chaos he, being a poet, can occasionally summon the clear note of sympathy, the pure colour of sense. If he would do this more often, 
he would be a finer writer even than he is. (1932: 6)

The repetition of 'genius' (a term which was then quoted on advertisements) shows the paradoxical position of Ford in the literary field. In Britain and in America, he was a highly respected writer with a certain degree of fame (his photograph was reproduced in the New York Times and the Illustrated London News, to give just two examples). ${ }^{21}$ And yet, his low sales and volatile relationships with publishers closed the door to the long-term recognition he so intensely desired.

\section{Ford's exclusion from prominent series of classics}

By the late 1920s and early 1930s, it became clear that Ford was also missing another opportunity to have his books marketed as 'classics.' None of the most prominent series of classics, in the US, UK and Continental Europe, included his work. Here, it is important to distinguish between an inexpensive edition that is simply a reprint of the original book, and an edition included in a series of classics. For example, in 1927, Grosset \& Dunlap issued Ford's Some Do Not... in a cheap edition in the United States. But Grosset \& Dunlap books were not marketed as part of a series, in contrast to Modern Library reprints. As Jay Satterfield notes, a Modern Library book was designed 'to be something more, an entity beyond the original work, as an integral part of a recognizable series with its own established reputation for excellence' (2002: 27).

Take the example of Joseph Conrad, with whom Ford had collaborated for a decade. In 1931 and 1932, Lord Jim and Victory were reprinted in the Modern Library. It had taken many years for the owners, Bennett Cerf and Donald Klopfer, to be able to add Conrad to their list: Doubleday initially refused to sell the reprints rights, and it was only after the Modern Library bought the Sun Dial Library that they were able to transfer the Conrad titles to their own series. ${ }^{22}$ In 1935 , Lord Jim was included in Everyman's Library, the most extensive reprints series in the UK (the book was number 925 on the list). Tauchnitz, a long-standing series sold in Continental Europe, reprinted multiple titles by Conrad up to the late 1930s. Unlike Conrad, Ford failed to benefit from the large 
markets opened up by these cheap series widely read by students, lower-middle-class and middleclass readers.

Even younger writers that Ford had mentored were well represented in the Modern Library, Everyman's Library and Tauchnitz series. D.H. Lawrence's Sons and Lovers, The Rainbow and Women in Love joined the Modern Library in 1923, 1927 and 1937 respectively. In the late 1920s and 1930s, Tauchnitz also reprinted several titles by Lawrence. More surprisingly, even the ultraconservative Everyman's Library had Lawrence on its list, starting with The White Peacock in 1935. Titles by Ernest Hemingway could also be found in the Modern Library and the Travellers' Library published by Jonathan Cape (the leading '3-shilling-and-6-pence' series, which specialized in copyrighted texts for a mainly British audience). Tauchnitz did not include any texts by Hemingway, but it published Tarr by Wyndham Lewis in 1931, three years after the Phoenix Library had issued the novel in a revised edition. ${ }^{23}$

While none of the market leaders included Ford titles, The Good Soldier was reprinted in John Lane's Week-End Library in $1928 .^{24}$ Like the Travellers' Library, the Week-End Library was a hardcover pocket series sold for three shillings and six pence. But while Jonathan Cape's series had its own brand identity (with a logo engraved in the binding and reproduced in advertisements), John Lane's library simply looked like a cheaper edition of the original. Titles were not numbered, another sign that the series lacked the coherence of a strong brand (other reprints series arranged their titles by numbers on special display racks, and encouraged readers to collect all of them). ${ }^{25}$ Advertisements gave a list of authors and titles included in the Week-End Library, without any appealing visuals or innovative design. In April 1928, an advertisement in the Times Literary Supplement announced the publication of the 'first twenty volumes of the Week-End Library,' adding that among the authors are 'G. K. Chesterton, John Buchan, Anatole France, Vernon Lee, Stephen Leacock, J. B. Priestley, Lascelles Abercrombie and Richard Garnett. ${ }^{26}$ Ford Madox Ford was not mentioned, even though The Good Soldier had been added to the series two months before. A review in the Daily Mail described the book as 'an attractive little story' and invited readers to 
'judge for themselves the final goodness of the soldier. ${ }^{, 27}$ Despite the mass-market audience of this newspaper, it is likely that the readership for The Good Soldier remained very limited. ${ }^{28}$ A year after the publication of the book, Ford wrote to J.B. Manson: 'My sales in England are so small that I have nearly come to the conclusion not to publish there at all. ${ }^{29}$

Ford was in demand not for his own work, but for writing introductions to other writers' works reprinted in prominent series of reprints. His preface to Guy de Maupassant's Stories was included in the 1927 Travellers' Library edition. ${ }^{30}$ And in 1932, Bennett Cerf asked him to introduce Hemingway's A Farewell to Arms in the Modern Library. Cerf later remembered meeting Ford at Horace Liveright's office in the 1920s. Liveright was famous for his wild parties, filled with beautiful girls and bootleggers. 'Free liquor! And interesting people,' as Cerf put it. And he added:

Well, for that particular party, I remember Ford Madox Ford arriving. He was the man who wrote The Good Soldier. He was terribly fat. He sat down on the brand new rattan couch, and with a terrible crash he went right through it. I'll never forget that. It was a great day. ${ }^{31}$

This anecdote is not insignificant, as it shows Ford was actively participating in the social life of the New York literati and building relationships with people who later proved useful to his career (for example, his novel When the Wicked Man was published by Liveright).

But Cerf was much less interested in Ford than in his protégé Hemingway. In 1927, he tried to add The Sun Also Rises to the Modern Library, but the original publisher Scribner refused to sell the rights. ${ }^{32}$ One year later, Cerf appealed to Hemingway directly. 'We are very anxious indeed to add a book of yours to our Modern Library series,' wrote Cerf. 'Your name belongs on our list, we feel, and we would be willing to pay you a royalty that, I am sure, would please you, to get it there. ${ }^{33}$ Eventually, Scribner accepted Cerf's increased offer of a $\$ 6,000$ advance against royalties of 12 cents a copy. ${ }^{34}$ As in the case of Willa Cather's Death Comes for the Archbishop (reprinted in the Modern Library in 1931), ${ }^{35}$ Cerf knew that Hemingway titles would be difficult to get, and he was prepared to offer a generous advance royalty. The Modern Library issued The Sun Also Rises in 
1930, with an introduction by Henry Seidel Canby (Hemingway had declined Cerf's suggestion to write his own preface). ${ }^{36}$

Two years later, Cerf cabled to Ford in Paris to ask him to write the introduction to $A$ Farewell to Arms, offering $\$ 75 .^{37}$ That was a large fee by the Modern Library standards (in 1933, Cerf offered Erskine Caldwell $\$ 50$ to write the preface to his novel God's Little Acre). ${ }^{38}$ Ford's name appeared on the dust jacket of the Modern Library edition, adding significant appeal to the book (Figure 1). Ford knew that his name was, in Mizener's phrase, 'a valuable commodity' (1971: 437). He later told the publisher Stanley Unwin: 'I am unquestionably one of the most eminently high-brow - I don't say invariably best-selling, writers they [America] have and a great many publishers have paid me quite large sums merely to have my name on their list. ${ }^{39}$ Ford's position in the US literary field was quite similar to that of Gertrude Stein. Like Stein, he was famous but had a reputation for writing difficult texts. ${ }^{40}$ And like Stein, he was associated with the 1920 s Paris scene, at the time when expatriates were coming back to America (temporarily or for good) and writing the myth. The Autobiography of Alice B. Toklas appeared in 1933; Malcolm Cowley's Exile's Return in 1934. The introduction that Ford wrote for A Farewell to Arms belongs to this genre of expatriates' memoirs. 'Those were exciting times in Paris,' wrote Ford. 'The Young-American literature that today forms the most important phase of the literary world anywhere was getting itself born there' (1932: 248). Ford positioned himself at the center of this literary scene: 'You should have seen those Thursday tea-parties at the uncapitalled transatlantic review offices!' (249). The introduction was arguably less about Hemingway than about Ford himself, who celebrated his own ability to discover young talents. 


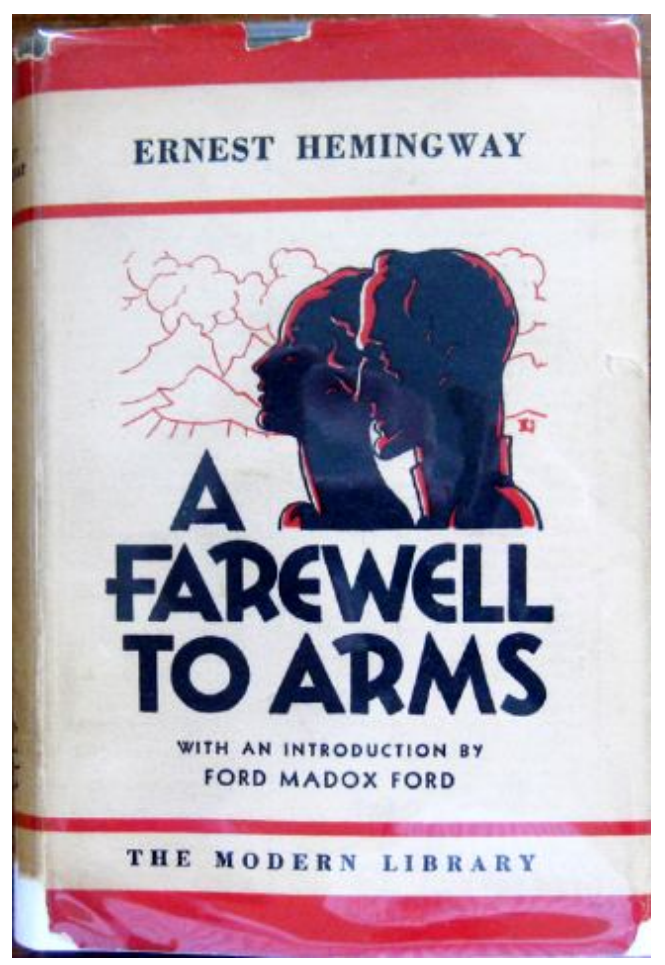

Figure 1: Dust jacket, Hemingway's $A$ Farewell to Arms (Modern Library edition, 1932)

When commissioning new introductions, the Modern Library hoped to attract the attention of journalists (who seldom reviewed reprint editions). Reacting to Ford's praise of Hemingway's style ('I wish I could quote more, it is such pleasure to see words like that come from one's pen'), the Christian Science Monitor wrote:

It may be a pleasure to Ford Madox Ford, but it's not a pleasure to us... If that passage had been written by a child, you would say that the child, after studying grammar and rhetoric, might perhaps learn to write at least correctly...which, of course, would ruin him for Mr Ford. (Sloper 1932: 6)

Ford's introduction did not convince everybody, but it was widely read. The Modern Library printed at least 46,000 copies of A Farewell to Arms in the first ten years after publication and the edition stayed in print for twenty-one years. ${ }^{41}$

While university instructors could easily select books by Hemingway, Lawrence or Joyce for their courses, it would have been difficult to teach Ford's work because no cheap edition was 
available. Let's take the example of Granville Hicks, who was teaching an upper-level course on modern literature at Smith College. In 1928, he assigned his class the Modern Library editions of Lawrence's Sons and Lovers, Joyce's Dubliners, Sherwood Anderson's Winesburg, Ohio and H.G. Wells's Ann Veronica. ${ }^{42}$ In a 1930 article entitled 'Ford Madox Ford, a Neglected Contemporary,' he wrote:

This is not a tale of a lonely genius, left to starve in the conventional garret, bequeathing to the world a slender manuscript of exquisite verse or a few pages of miraculous prose. It is a much more puzzling story, the story of a man who has been in the thick of every literary fray and yet is ignored by the literary historians, a man whose individual books have, as they appeared, been greeted as unusual achievements but whose work as a whole has made little impression on the contemporary mind. In several rather detailed studies of modern literature his name is not even mentioned, and no one, so far as I know, has ever made an effort to estimate his importance. Everyone knows he exists - it would be rather hard, all things considered, to ignore the fact—-but there are few people who could accurately tell you what he has done. (1930: 364)

Hicks pointed out an important characteristic of the reception of Ford's texts: initial good reviews were followed by critical apathy. One explanation for this neglect is that publishers did not keep Ford's books in print, making it more difficult to study and to teach his work at the time when the canon of modern literature was being established.

It was not until after Ford's death in 1939 that his work was reprinted for a large audience. In 1946, Penguin Books published a paperback edition of The Good Soldier followed two years later by the four volumes of the Tietjens tetralogy: Some Do Not..., No More Parades, A Man Could Stand Up-- and Last Post. It was the first time that readers in Britain could buy Ford's books for such a cheap price (1 shilling in 1946). Penguin's interest in Ford is rather difficult to explain: he had never been commercially successful in the UK and no series of classics had kept his work in 
print. Since Penguin titles had to sell between 17,000 and 20,000 copies to break even, the firm avoided reprinting 'highbrow' titles with a limited audience. As Raymond MacKenzie puts it, the variety of the Penguin list 'was calculated to appeal to the widest range of readers possible.' So how can we explain that Penguin issued not one but five Ford titles in just three years (1946-1948)? The firm perhaps hoped that Ford's success in America could be replicated in Britain. The back cover of the Penguin edition of The Good Soldier stated: 'his later years were divided between that country [France] and America, where the publication of the Tietgeus (sic) books (Some Do Not..., No More Parades, A Man Could Stand Up-), brought him much fame.' Immediately after the Second World War, Penguin also reprinted D.H. Lawrence's work: Sea and Sardinia in 1944, followed by The Prussian Officer (1945), Sons and Lovers (1948), The Rainbow (1949) and ten other titles published for the twentieth anniversary of Lawrence's death in 1950. Writers like Ford and Lawrence who had once been thought difficult or controversial were now made available to the masses in paperback editions. $^{43}$

In conclusion, Ford's constant disappointment with his publishers pushed him to extend his network of contacts in the hope of finding better deals. Without this drive, Ford might have stayed an obscure English writer. Instead, he built his reputation in America with an impressive determination. Although he never got the collected edition he desired, and no prominent series of classics reprinted his work in the interwar period, Ford left enough footprints to be rediscovered after his death. Without the commercial success of Parade's End in the United States, it is doubtful that Penguin would have issued a paperback edition of the tetralogy in Britain after the Second World War. And the contacts that Ford made in America helped maintain his posthumous legacy, leading to an increase of scholarly interest in the 1960 s.

While this chapter has focused mostly on publishers and their role in shaping the literary canon, there are many other ways to 'do book history' in relation to Ford studies. For example, book historians have been increasingly interested in literary agents' role in shaping literary 
production. Mary Ann Gillies's The Professional Literary Agent in Britain, 1880-1920 focuses on A.P. Watt and James Pinker - and includes several references to Ford. Yet, the correspondence between Ford and Pinker (held at the Huntington Library) has not been sufficiently studied. Another interesting research topic would be to compare the marketing of UK and US editions of Ford titles. Their physical format (dust jackets, binding, paper) and advertising materials would shed light on the way in which Ford was positioned in the British and American literary fields. Historians of reading and printing could also add interesting insight to Ford studies. Vice versa, Ford scholars could do more to share their research findings at book history conferences. In short, crossfertilization between the two fields would increase our scholarly appreciation of Ford and the development of his career.

\section{BIBLIOGRAPHY}

Ardis, A. (2015) 'Modernist Print Culture,' American Literary History 27.4 813-19.

Brooker, P., and A. Thacker, eds (2009-2013) The Oxford Critical and Cultural History of Modernist Magazines, 3 vols, New York: Oxford UP.

Butcher, F.. (1931) 'Ideas Wander, Homelessly, in This New Book,' Chicago Daily Tribune 23 May.

Chamberlain, J. (1931) 'New York's Dizzy Life in Mr Ford's New Novel,' New York Times 24 May.

Chantler, A., and R. Hawkes, eds (2015) An Introduction to Ford Madox Ford, Farnham: Ashgate.

Ciabattari, J. (2015) 'The 100 Greatest British Novels,' BBC, Web. 7 Dec.

$<$ http://www.bbc.com/culture/story/20151204-the-100-greatest-british-novels $>$

Collier, P. (2016) Modern Print Artifacts: Textual Materiality and Literary Value in British Print Culture, 1890-1930s, Edinburgh: Edinburgh UP.

Colombino, L., and M. Saunders, eds (2013) The Edwardian Ford Madox Ford, vol. 12, International Ford Madox Ford Studies, Leiden: Brill. 
Darnton, R. (1982) 'What Is the History of Books?' Daedalus 111.3 65-83.

Deer, P. (2012) ' 'Scattered but All Active': Ford Madox Ford and Transatlantic Modernism,' Ford Madox Ford and America, ed. S. Haslam and S. O’Malley, vol. 11, International Ford Madox Ford Studies, Leiden: Brill, 69-84.

Feltes, N.N. (1993) Literary Capital and the Late Victorian Novel, Madison: U of Wisconsin P.

Ford, F. Madox (1932) 'Introduction to Ernest Hemingway, A Farewell to Arms,' The Ford Madox Ford Reader, ed. Stang, 246-54.

--- (2012) The Good Soldier, Oxford: Oxford UP (World's Classics).

Gillies, M.A. (2007) The Professional Literary Agent in Britain, 1880-1920, Toronto: University of Toronto Press.

Gould, G. (1932) 'New Novels,' Observer 12 June.

Harvey, D.D. (1962) Ford Madox Ford, 1873-1939: A Bibliography of Works and Criticism, Princeton: Princeton UP.

Haslam, S. (2013) 'Ford as Edwardian Author: Publishers, Trends, Markets,' The Edwardian Ford Madox Ford, ed. Colombino and Saunders, 35-48.

Hicks, G. (1930) 'Ford Madox Ford, A Neglected Contemporary,' Bookman Dec. 364-70.

Jaillant, L. (2014a) Modernism, Middlebrow and the Literary Canon: The Modern Library Series, 1917-1955, London: Routledge.

--- (2014b) 'Rewriting Tarr Ten Years Later: Wyndham Lewis, the Phoenix Library and the Domestication of Modernism,' Journal of Wyndham Lewis Studies 5 1-30.

Joyce, J. (1966) Letters of James Joyce, ed. R. Ellmann, vol. 3, London: Faber and Faber, 3 vols. Judd, A. (1990) Ford Madox Ford, London: Collins.

Ludwig, R.M., ed. (1965) Letters of Ford Madox Ford, Princeton: Princeton UP.

MacKenzie, R.N. 'Penguin Books,' British Literary Publishing Houses, 1881-1965, ed. Rose and Anderson.

Mao, D., and R.L. Walkowitz (2008) 'The New Modernist Studies,' PMLA: Publications of the 
Modern Language Association of America 123.3 737-48.

Mizener, A. (1971) The Saddest Story: A Biography of Ford Madox Ford, London: Bodley Head.

Morrisson, M.S. (2001) The Public Face of Modernism: Little Magazines, Audiences, and Reception, 1905-1920, Madison: U of Wisconsin P.

'Notes for the Novel Reader - Fiction of the Month' (1932) Illustrated London News 6 Aug.

O’Malley, S. (2012) 'America's Ford: Glenway Wescott, Katherine Anne Porter and Knopf's

Parade's End,' Ford Madox Ford and America, ed. S. Haslam and S. O'Malley, vol. 11, International Ford Madox Ford Studies, Leiden: Brill, 97-108.

Rose, J., and P. Anderson, eds (1991) British Literary Publishing Houses, 1881-1965, Detroit: Gale Research, vol. 112 of Dictionary of Literary Biography.

Satterfield, J. (2002) The World's Best Books: Taste, Culture, and the Modern Library, Amherst: U of Massachusetts P.

Saunders, M. (1996) Ford Madox Ford: A Dual Life, 2 vols, New York: Oxford UP.

--- (2015) 'Impressions of War: Ford Madox Ford, Reading and Parade's End,' Reading and the First World War: Readers, Texts, Archives, ed. S. Towheed and E.G.C. King, Basingstoke: Palgrave Macmillan, 63-77.

--- (2013) 'Introduction: Edwardian Ford?' The Edwardian Ford Madox Ford, ed. Colombino and Saunders, 13-32

Sloper, L.A. (1932) 'Bookman’s Holiday,' Christian Science Monitor 4 June.

Snyder, C. (2012) “More Undraped Females and Champagne Glasses': Ford Madox Ford's Ambivalent Affair with Mass Culture,' Ford Madox Ford and America, ed. S. Haslam and S. O’Malley, vol. 11, International Ford Madox Ford Studies, Leiden: Brill, 139-53.

Stang, S.J., ed. (1986) The Ford Madox Ford Reader, Manchester: Carcanet.

Sutherland, J. (1988) 'Publishing History: A Hole at the Centre of Literary Sociology,' Critical Inquiry 14.3 574-89.

Tomlinson, N. (2010) ““An Old Man Mad about Writing” but Hopeless with Money: Ford Madox 
Ford and the Finances of the English Review,' Ford Madox Ford, Modernist Magazines and Editing, ed. J. Harding, vol. 9, International Ford Madox Ford Studies, Leiden: Brill, 14351.

Wiesenfarth, J. (1991) 'Fargobawlers: James Joyce and Ford Madox Ford,' Biography 14.2 95-116. Willis, J.H. (1992) Leonard and Virginia Woolf as Publishers: The Hogarth Press, 1917-41, Charlottesville: UP of Virginia.

\footnotetext{
${ }^{1}$ I am grateful to Kirsten MacLeod for her assistance.

${ }^{2}$ See, for example, Sara Haslam's 2013 essay 'Ford as Edwardian Author: Publishers, Trends, Markets' and Max Saunders’s 1996 biography of Ford.

${ }^{3}$ Howsam, 'The Practice of Book and Print Culture: Sources, Methods, Readings,' Perils of Print Culture Conference, Trinity College Dublin, 10 Sept. 2010, keynote speech.

${ }^{4}$ Information about Ford's publishers can be found in Saunders's and Judd's biographies (1996 and 1990). See also The Edwardian Ford Madox Ford, ed. Colombino, and Saunders (2013).

${ }^{5}$ A collected edition (i.e. a comprehensive edition of the writings of a particular author) is generally uniform - all the books have the same physical format. Collected editions can be included as part of a uniform series of classics: for example, from 1928, Chatto \& Windus included its backlist of Aldous Huxley's books in a cheap series (the Phoenix Library).

${ }^{6}$ See Chantler and Hawkes (2015); and the 2012 Oxford World's Classics edition of The Good Soldier, with an introduction by Max Saunders. The Good Soldier and Parade's End are also available in Penguin Classics editions, widely used in classrooms.

${ }^{7}$ Ford to Hinton, 13 Feb. 1928 (qtd in Harvey 1962: 64).

${ }^{8}$ Ford was not, of course, the only writer to complain about his publishers (Edith Wharton was often unsatisfied with the way her publishers marketed her work, for example).

${ }^{9}$ Ford to Baumgarten, 10 July 1929 (qtd. in Ludwig 1965: 185).

${ }^{10}$ Ford to Secker, 18 Aug. 1918 (qtd. in Ludwig 1965: 88-89).

${ }^{11}$ Ford to Pinker, 13 Feb. 1914 (qtd. in Ludwig 1965: 59).

${ }^{12}$ L. Woolf to Gerald Duckworth, 10 Dec. 1928, MS 2750/546, Hogarth Press archive, U. of Reading.

${ }^{13}$ Ford to Pinker, 8 July 1920 (qtd in Stang 1986: 479).

${ }^{14}$ As Patrick Deer points out (2012), the category of 'transatlantic modernism' can productively be applied to Ford. But again, scholars have mostly focused on the case of the transatlantic review, and neglected Ford's ability to deal with book publishers across the Atlantic.

${ }^{15}$ Ford to Latham, 14 Aug. 1921 (qtd. in Stang 1986: 483).

${ }^{16}$ Ford to Jepson, 15 Aug. 1922 (qtd. in Ludwig 1965: 143).
} 
${ }^{17}$ See O’Malley 2012: 98.

${ }^{18}$ Ford to Oppenheimer, 9 Nov. 1928 (qtd. in Ludwig 1965:182).

19 'Lippincott's reply to Ford's proposal of a collected edition was reported to Ford by Jenny Bradley, 6 Dec. 1933' (Mizener 1971: 594 n19).

${ }^{20}$ Ford also fictionalises the publishing world in Ladies Whose Bright Eyes (first published in 1911 and then revised and re-published in 1935) through the protagonist Sorrel.

${ }^{21}$ Chamberlain; 'Notes for the Novel Reader.'

${ }^{22}$ Announcement from Bennett Cerf to booksellers, 16 April 1930, box 36, Cerf papers, Columbia University (hereafter referred to as $\mathrm{CP})$.

${ }^{23}$ For more on Tarr in the Phoenix Library edition, see Jaillant 2014b.

${ }^{24}$ Since John Lane had published the first edition of The Good Soldier in 1915, the firm already had the rights for this title.

${ }^{25}$ See Jaillant 2014a: 65.

${ }^{26}$ Advertisement for John Lane - The Bodley Head, Times Literary Supplement 12 April 1928.

${ }^{27}$ Review of The Good Soldier, Daily Mail 16 March 1928.

${ }^{28}$ A search in databases (News Vault and ProQuest Historical Newspapers) shows only one advertisement that mentions this edition of The Good Soldier (in The Bookman of February 1928) and only one review (in the Daily Mail). In contrast, the Phoenix Library edition of Wyndham Lewis's Tarr (also published in 1928) continued to be advertised until at least 1935 and was reviewed in several periodicals.

${ }^{29}$ Ford to Manson, 11 Jan. 1929 (qtd. in Stang 1986: 493).

${ }^{30}$ The preface had already appeared in a 1903 edition published by the Greenback Library.

${ }^{31}$ Reminiscences of Bennett Cerf (c. 1967), session 3, p. 120, Oral History Research Office Collection, Columbia University.

${ }^{32}$ Cerf to Scribner, 17 Sept. 1927, box 130, Random House records, Columbia University (hereafter referred to as RH).

${ }^{33}$ Cerf to Hemingway, 29 Oct. 1928, box 85, RH.

${ }^{34}$ Gordon B. Neavill, The Canon in the Marketplace: A Descriptive Bibliography of the Modern Library Series, 1917-1986, forthcoming.

${ }^{35}$ See Jaillant 2014a: 103-22.

36 'I am glad you are doing the book but I am sorry I cannot write a foreword for it - I cannot write a foreword for anything least of all a book I wrote myself.' Hemingway to Cerf, 4 Jan. 1930, box 1, CP.

${ }^{37}$ Cerf to Ford, 18 Jan. 1932, box 85, RH.

${ }^{38}$ Cerf to Caldwell, 12 Oct. 1933, box 71, RH.

${ }^{39}$ Ford to Unwin, 15 March 1938 (qtd. in Mizener 1971: 437).

${ }^{40}$ In a review of When the Wicked Man in the Chicago Daily Tribune, Fanny Butcher wrote that Ford's novel was 'confusing' and unfavorably compared it to Joyce's Ulysses ('There are, as it seems to me, two kinds of confusing books in these days, the Ulysses type and the unmotivatedly confusing type' [1931]). 
${ }^{41}$ In the early 1950s, Scribner decided to cancel their contracts for the Hemingway titles in the Modern Library, in order to promote the titles themselves. Whitney Darrow to Cerf, 29 Oct. 1952, box 21, RH.

${ }^{42}$ Hicks to Modern Library, 25 Jan. 1928, Catalogued Correspondence, RH.

${ }^{43}$ While this chapter has focused primarily on the first half of the twentieth century, more work needs to be done on editions published after 1950 (including the Bodley Head edition, which shaped the Fordian canon from the 1960s). 